\title{
을
}

\section{Energy Protests and Citizen Voice}

Recent years have seen energy protests erupt in many countries around the world. Globally, countries are wrestling with the need to achieve a just transition away from fossil fuels while at the same time ensuring access to affordable energy. Protests often have a common root cause: the undemocratic nature of energy policymaking. This Policy Briefing describes findings from research conducted in Mozambique, Nigeria, and Pakistan, as well as from a global, cross-country study, and the insights from an International Roundtable. It asks how and under which conditions do struggles over energy in fragile and conflict-affected settings empower citizens to hold public authorities to account?

\section{Key messages}

- Access to affordable energy is regarded by most citizens as a right in Nigeria, Pakistan, and Mozambique, and in most countries of the world.

- Energy policymaking is often opaque, sometimes corrupt and, in the three countries studied, almost entirely lacking in any attempt to engage citizens.

- International energy businesses and development partners have tended to treat energy policy as a technical field and have typically devoted minimal effort to ensuring citizen participation or improving accountability and transparency in the sector.

- The absence of credible mechanisms of consultation or ways of expressing grievances means that citizens often resort to protest when governments implement large fuel or electricity price increases.

- A just transition globally will only be possible with much greater engagement of citizens about energy policies.
3

Energy protests often have a common root cause: the undemocratic nature of energy policymaking. 


\section{Introduction}

As world leaders prepare to meet in

Glasgow for the 2021 UN Climate Change Conference of the Parties (COP26), there is much talk about how to achieve a global 'energy transition' to clean energy. But for many living in poor or fragile countries or regions, the issue is not one of transition; it is about affordable access to energy for their everyday lives (regardless of how that energy is generated). Recent months have shown how external shocks - coupled with mismanagement of energy policies - can give rise to large price shocks for consumers in rich and poor countries, frequently leading to angry protests. But do such protests work? Do they make energy policy more accountable to citizens? Do they help facilitate access to affordable energy? And do they support a just transition to cleaner energy?

The Action for Empowerment and Accountability (A4EA) research programme report Demanding Power: Do Protests

\section{Empower Citizens to Hold Governments} Accountable Over Energy? describes the key findings from interdisciplinary closegrained studies of energy protests in Mozambique, Nigeria, and Pakistan, as well as global cross-country analysis. Based on detailed analysis of the literature, interviews, focus group discussions, and the collection of cultural and media expressions of protest, the research asked:

- What political and economic conditions drive energy protests?

- Do major episodes empower people to hold their governments accountable for energy provisioning?

- How do external and transnational interests shape the conditions in which mass protests unfold?

On concluding the research, A4EA brought together leading experts from around the world for an International Roundtable to discuss the findings. This Policy Briefing

\section{Energy protests can have significant and far-reaching impacts... however, there is limited evidence that the raw power of energy protests leads to empowered citizens with respect to energy policy over time.}

summarises the key messages from the research and the Roundtable and puts forward recommendations for how energy policies can be improved by ensuring greater engagement with citizens.

\section{Findings}

Energy protests have been recurrent and significant political events in the twenty-first century. Between 2005 and 2018, 41 countries had at least one riot directly associated with popular demand for affordable fuel. Major protests have erupted in countries rich and poor; in places with strong and stable states (France, Chile) as well as where states are fragile and conflict common (Mozambique, Haiti); in energy exporting countries (Nigeria, Mozambique) and those dependent on imports (India, Lebanon). There have been localised protests about electricity and urban uprisings about fuel prices or transport fares. Some countries have had both these types of protest as well as others, including those around new energy deals, infrastructure, and transnational campaigns against fossil fuels.

\section{Why do energy protests happen?}

\section{Cross-country evidence shows that price} shocks - such as fuel or electricity price rises - are the key driver of energy protests. These shocks often result when unsustainable energy subsidies - commonly caused by 
fixing domestic prices below international prices - are reduced or removed. Countries with poor governance, high corruption, and less civil society freedom tend to have higher subsidies. The same is true for countries that are net energy exporters, such as major oil exporters. However, the evidence suggests that, rather than protecting citizens from shocks, energy subsidies increase the likelihood of riots. This is because the price changes introduced when such subsidies become financially unsustainable are much larger than those that occur in countries with more flexible energy prices.

\section{What do protests achieve?}

Energy protests can have significant and far-reaching impacts, including injury and loss of lives, damage to property and, not uncommonly, major political upheaval sometimes triggering government collapse. However, the research found limited evidence that the raw power of energy protests leads to empowered citizens with respect to energy policy over time. Meaningful gains in citizen power were short-lived or diffuse, dissipating without institutionalised citizen engagement or lasting organisations. Major protest episodes taught protestors that, en masse, they could force the government to hear their complaints, but they rarely elicited more than a heated public hearing followed by often temporary policy change.

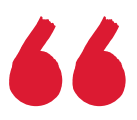

\section{New and better approaches to engaging citizens in energy policy processes should be developed to increase the chances of policies being tailored to the needs of the people.}

\section{Why is energy so contentious?}

The A4EA Demanding Power research project points to two reasons.

First, access to affordable energy for everyday life is regarded by citizens in Mozambique, Nigeria, and Pakistan and around the world - as a basic right. Modern life requires access to affordable sources of energy and citizens believe that it is the government's responsibility to ensure that it is available. In short, the provision of energy is seen as part of the 'social contract'.

Second, there are few, if any, formal channels - political parties, civil society, independent media - whereby citizens are consulted on, or able to engage in dialogue with policymakers about energy policy. As a result, when faced with a major shock such as a rise in the price of fuel or electricity, citizens feel they have no alternative other than to protest to make their voices heard.

State tactics were to ward off protests, but rarely involved a visible strategy of strengthening public accountability for energy policy.

However, protests have other effects. Protests can create or contribute to fragility, depending on how governments respond. In some cases, protests led to governments delaying the introduction of reforms. For example, in Nigeria, government efforts to reform fuel subsidies in the interests of reducing fiscal imbalances (as well as improving equity) have repeatedly been put on hold because of fears of mass protests against higher-priced energy. In Pakistan, hundreds of protests against erratic electricity supply forced the issue onto the political agenda, but electricity policymaking remains opaque, elitist, and 
technocratic, and no spaces or institutional practices were created to give citizens voice over their power supply. In other contexts, protests led to state repression. In Mozambique, the food and fuel protests of 2008 and 2010 saw the state deploy extreme violence against protestors to suppress any nascent struggles. In none of these three countries did the political party in power have any incentive to reform energy policies in which powerful interests were invested, and there were no innovations with respect to how to address citizens' energy grievances beyond violence or short-term appeasement.

\section{What is the role of international actors?}

Transnational actors - such as multinational energy business, banks, and multilateral development banks - are part of the landscape of energy protests, but their roles can be hidden or obscure. On the one hand, multilateral aid actors tend to influence national energy subsidy reform, more by shaping the policy pathways open to governments than through the 'hard' conditionality of structural adjustment. On the other, multinational companies and foreign governments take a more direct approach to influencing national energy policy globally, but these well-resourced powerful interests help ensure energy policymaking remains closed and secretive. Aid donor support for civil society and good governance has rarely supported popular domestic movements for climate justice or

\section{“}

\section{Creating global and national policy spaces for social movements and civic activism will be crucial to progress towards energy justice.}

energy security and transnational climate movements focus on cutting fossil fuel use and play no role in popular protests against energy price rises in the global South. While energy price protests in the global South seem at odds with activism against fossil fuels in the North, both share a concern with the need for civic participation, transparency, and accountability in energy policymaking.

\section{Discussion}

An International Roundtable on 20 September 2021 provided an opportunity for leading experts from government, multilateral organisations, citizen groups, and academia to discuss the research findings. Key points from the discussion included:

A taxonomy of protest: There are lots of different types of energy-related protest, so it is important to understand the similarities and differences between them. In particular, why do some price increases for fuel or electricity give rise to protests while others do not? A better understanding of the wider political and economic context may help to explain how energy policies interact with other concerns leading to protest, and therefore how to structure reforms and citizen engagement to gain wider acceptance of changes.

We need a taxonomy of protest... to understand why some things lead to protest while others do not.

(Vivien Foster, Chief Infrastructure Economist, World Bank)

\section{Protests can result in change... but} intermediaries are needed: One participant argued that protests in several countries (e.g., Egypt, Senegal) had been quite successful in making energy policy more responsive to citizens' needs. However, protestors are not homogeneous; they have different needs (and different views). There is also a need for greater capacity in intermediaries - including a wide variety of civil society 


\section{Energy policymakers worldwide should put in place mechanisms to consult, engage, and listen to citizens - particularly on the issue of energy subsidy reforms as well as the systemic changes needed to transition to clean energy.}

groups such as non-governmental organisations and unions - to ensure that citizens' voices are heard.

\section{Corruption and short-term responses} lead to high costs: A senior government participant pointed out that protestors often reject price rises because they reflect high costs of energy supply caused by non-transparent and sometimes corrupt contracts. Responding to protests in the short run through emergency measures leads to even higher costs because energy assets are long-lived and subject to longterm contracts, so consumers end up being stuck with these high costs for a long time. It is therefore important that investment decisions in the energy sector are informed by long-term, integrated, least-cost planning.

\section{Bridging shortages for the non-} productive peak load is very expensive for developing countries and only serves a relatively small population... Poorly conceived generation projects have an impact-lag due to long gestation periods and consequences are for long period due to term of the power purchase agreements.

(Waqas bin Najib, Member (Energy) at the Planning Commission of Pakistan)
From accountability to pre-accountability:

The accountability challenge is not just to ensure accountability for policies adopted and actions taken. 'Pre-accountability' is about having people involved in the design of energy policies and pathways in the first place. Anticipating and thinking through the impacts of energy policy changes on society helps policymakers see where the flashpoints are going to be. Depending on the issue, a range of tried and tested formats exist to enable citizen participation and engagement (e.g., climate assemblies).

\section{The urgency of climate action vs the} gradualism of inclusiveness: One participant contrasted the need for urgent action with the slower pace usually associated with inclusive or participatory policy processes. Others argued that the two were not in conflict - that an inclusive process is needed to ensure widespread acceptance of change which is essential to rapid action; change without acceptance leads to backlash, slowing reform.

\section{Unless you have buy-in you will have backlash. \\ (Peter Newell, Professor of Global Political Economy, University of Sussex)}

Energy protests are political events: Energy protests are not just about energy - they are political events. Access to cheap fuel is seen as an entitlement, especially in countries which have oil. Sharp rises in the price are regarded as breaches of the social contract. Where people do not have faith in the formal political system to listen to their views, they resort to protest as a way of getting their governments to pay attention.

We have not pivoted protest... into voice. (Yemi Adamolekun, Enough is Enough/ Office of the Citizen, Nigeria) 


\section{Policy recommendations}

Energy policymaking by both national and international actors needs to better understand the political dimensions of energy sector reforms. New and better approaches to engaging citizens in energy policy processes should be developed to increase the chances of policies being tailored to the needs of the people and to strengthen the social contract between citizens and states. This will also be key if countries are to implement just transitions towards the use of more environmentally-sustainable energy sources.

\section{- Energy policymakers worldwide}

should put in place mechanisms to consult, engage, and listen to citizens particularly on the issue of energy subsidy reforms as well as the systemic changes needed to transition to clean energy.

- Donors and development partners should support the inclusion of civil society in dialogue about, and participation in, the design and formulation of energy policy. They should also demand greater transparency by government and the business sector in procurement and contracting.
- International energy businesses should commit to transparency in the sector - particularly in contracts e.g., through publishing Power Purchase Agreements or Energy Supply Agreements and requiring suppliers to do the same.

\section{- International civil society organisations} should recognise the fundamentally different energy challenges faced by citizens in the global South. They should support their struggle for access and affordability, and the transition towards cleaner and more sustainable energy.

\section{- Civil society organisations in the global}

South should engage more on energy policy issues and press for greater transparency and accountability to citizens, and mechanisms for consultation, dialogue, and participation. As energy becomes more vital to everyday life for people across the world, livelihoods and lives will depend ever more on access to modern forms of energy. Creating global and national policy spaces for social movements and civic activism will be crucial to progress towards energy justice.
Institute of Development Studies, Library Road, Brighton BN1 9RE, United Kingdom +44 (0)1273 606261 ids.ac.uk IDS is a charitable company limited by guarantee and registered in England. Charity Registration Number 306371. Charitable Company Number 877338.

\section{Further reading}

Hossain, N. et al. (2021) Demanding Power: Do Protests Empower Citizens to Hold Governments Accountable over Energy?, IDS Working Paper 555, Brighton: Institute of Development Studies, DOI: 10.19088/IDS.2021.056

McCulloch, N.; Natalini, D.; Hossain, N. and Justino, P. (2021) An Exploration of the Association Between Fuel Subsidies and Fuel Riots, IDS Working Paper 556, Brighton: Institute of Development Studies, DOI: 10.19088/IDS.2021.058

Atela, M. et al. (2021) Demanding Power: Struggles over Fuel Access in Nigeria, IDS Working Paper 554, Brighton: Institute of Development Studies, DOI: 10.19088/IDS.2021.054

Javed, U. with Hussain, A. and Aziz, H. (2021) Demanding Power: Contentious Politics and Electricity in Pakistan, IDS Working Paper 551, Brighton: Institute of Development Studies, DOI: 10.19088/IDS.2021.047
This IDS Policy Briefing was written by Neil McCulloch (The Policy Practice), edited by Emilie Wilson (IDS) and supported by Jenny Edwards (IDS). It was produced as part of the Action for Empowerment and Accountability (A4EA) research programme, funded with UK Aid from the UK government (Foreign, Commonwealth \& Development Office - FCDO).

The opinions expressed are those of the authors and do not necessarily reflect the views or policies of IDS or the UK government.

\section{(c) Institute of Development Studies 2021.}

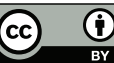

This is an Open Access briefing distributed under the terms of the Creative Commons Attribution 4.0 International licence (CC BY), which permits unrestricted use, distribution, and reproduction in any medium, provided the original authors and source are credited and any modifications or adaptations are indicated.

ISSN 1479-974X

DOI: 10.19088/IDS.2021.062 